\title{
Peatland ferruginization during late Quaternary in the Uberaba Plateau (South-Eastern Brazil)
}

\author{
Jean Dominique Meunier ${ }^{a, *}$, Angelica F.D.C. Varajão ${ }^{b}$, Cesar A.C. Varajão ${ }^{b}$, Fabrice Colin ${ }^{a}$, \\ Olivier Grauby ${ }^{\mathrm{c}}$ \\ ${ }^{a}$ Aix-Marseille Université, CNRS, IRD, CEREGE UM34, 13545 Aix en Provence, France \\ ${ }^{\mathrm{b}}$ DEGEO/EM/UFOP, Campos Morro do Cruzeiro, 35400-000 Ouro Preto, MG, Brazil \\ c Aix-Marseille Université, CNRS, CINaM, Campus de Luminy Case 913, 13288 Marseille, France
}

\section{A R T I C L E I N F O}

\section{Article history:}

Received 18 January 2012

Accepted 20 December 2012

\section{Keywords:}

Peatland

Iron duricrust

Brazil

Latosol

Oxidation

Carbon dynamics

Climate change

\begin{abstract}
A B S T R A C T
Due to the poor preservation of old peat formations and the limited research developed on them, the contribution of peat oxidation to the global $\mathrm{C}$ cycle at geological scales is poorly understood. Iron duricrusts containing abundant well-preserved plant structures have been reported above Humic Gleysols in the Uberaba Plateau (Brazil). We show that the iron accumulation results from an in-situ impregnation of peat, fast enough to preserve the plant structures. The formation of iron oxides results from two processes: precipitation in the pores and C/Fe replacement. The iron duricrusts were probably triggered by oxidation of the peatland following dry climatic events during the last $50 \mathrm{kyr}$. The large amount of iron dissolved in peatland waters was immobilized contemporaneously with the destruction of organic matter. The oxidation of organic matter from the lower peat, dated at ca $24-27 \mathrm{kyr} \mathrm{BP}$, may have released between 0.08 and $2.26 \mathrm{~kg} \mathrm{CO} \mathrm{m}^{-2} \mathrm{yr}^{-1}$ in the atmosphere. These rates are in a good agreement with present-day measurements of $\mathrm{CO}_{2}$ release from drained peatlands. Although peatland formation has been identified as a significant contributor to the global $\mathrm{CO}_{2}$ uptake, our findings suggest that natural peatland oxidation should also be considered as a source of atmospheric $\mathrm{CO}_{2}$ during past climate change. (C) 2012 Elsevier Ltd. All rights reserved.
\end{abstract}

\section{Introduction}

The oxidation of organic matter from peatland has become a major global concern because it can release significant $\mathrm{CO}_{2}$ into the atmosphere (Limpens et al., 2008; Joosten, 2009; Sorensen, 1993; Evans and Lindsay, 2010). Although the impact of peatland accumulation on climate radiative forcing is significant at the longterm scale (i.e. for Holocene: Frolking and Roulet, 2007), the consequences of environmental change on peatland oxidation is so far not documented by any paleosol or sedimentological data. The preservation of plants remnants requires a rapid replacement by an inorganic solid phase before destruction of the organic material (Pailler et al., 2000; Akahane et al., 2004). Such a fossilization is a priori not favorable to the preservation of peat features in an oxidizing environment. However, plant fossils are sometimes encountered in lateritic duricrusts (Grandin and Perseil, 1977;

\footnotetext{
* Corresponding author.

E-mail address: meunier@cerege.fr (J.D. Meunier).
}

Varajão et al., 2002, 2007) suggesting a replacement of carbon features by minerals stable in oxidizing environment such as iron oxides.

Goethite and hematite are two common minerals in iron duricrusts that are known to develop under tropical climate with strong seasonality (Tardy, 1993). Two mechanisms are proposed to explain the enrichment of these minerals in the iron duricrusts (Nahon, 1991; Thomas, 1994): 1) in-situ enrichment by weathering of iron-rich parent rocks, 2) lateral migration of $\mathrm{Fe}^{2+}$ in reduced or acid solutions and accumulation of $\mathrm{Fe}^{3+}$ oxides at the interface with an oxidizing, neutral to alkaline environment. Vegetation cover and biological activity in soil are assumed to play an important role in leaching iron from rocks through the local reduction of iron around roots where $\mathrm{pH}$ is lowered. Therefore, if iron is sufficiently mobilized in a peatland, any environmental changes leading to oxidation and destruction of peatland would be favorable to precipitation of iron oxides. The objective of this paper is to document this scenario as well as its consequences for $\mathrm{CO}_{2}$ release into the atmosphere.

At Uberaba Plateau (South-Eastern, Brazil), Varajão et al. (2002, 2007) reported on an iron duricrust containing plant fossils above a peat layer which may indicate peat oxidation and fossilization by 
iron oxi-hydroxides. In order to address if iron duricrusts at Uberaba are evidenced of peat oxidation during environmental changes, we have conducted a study combining mineralogy and geochemistry on the peat-duricrust interface reported by Varajão et al. (2002, 2007).

\section{Materials and method}

The study area has been the object of previous investigations including morphological, mineralogical and geochemical studies (Lara, 1997; Varajão et al., 2000, 2002, 2007). The climate is tropical with rainfall averages of $1550 \mathrm{~mm} /$ year, a dry season from April to October and a humid season from November to March. Average temperatures are $23.9{ }^{\circ} \mathrm{C}$ in the summer and $18.3^{\circ} \mathrm{C}$ in the winter. The Uberaba Plateau (Fig. 1) belongs to the Triângulo Mineiro region in the Minas Gerais state. The plateau is located at elevations between 940 and $980 \mathrm{~m}$, covers approximately $2000 \mathrm{~km}^{2}$ and is surrounded by $150 \mathrm{~m}$ high escarpments. Bedrock is composed of Proterozoic-age schists, gneiss and migmatites of the Araxá Group, covered by Mesozoic clastic rocks of the São Bento and Bauru Groups. The plateau encloses basins formed by gentle slopes that surround central depressions where peatlands have developed.

The landscape is covered by the "cerrado" biome, a major Brazilian savanna-like ecosystem (Oliveira and Marquis, 2002) that encompasses an extremely variable physiognomy, ranging from open grassland to forest with a discontinuous grass layer (Goodland, 1971). In the study area can be recognized the "cerrado sensu strict" in the high slope, the "campo sujo" in the medium slope associated to the earthmounds-bearing endemic trees and shrubs and, in the low slope the waterlogged grasslands. This former hydromorphic physiognomy consists of Poaceae and Cyperaceae with the Rhynchospora emaciata as the dominant species (Borba-Roschel et al., 2006).

The representative soil catena of the area (Varajão et al., 2000, 2002, 2007) is the following: 1) at high elevations: typical lateritic soil that is called Latosol in the Brazilian soil classification system (Embrapa, 2006) or Ferralsol (FAO, 1990); 2) at intermediate elevations: «earthmound fields» composed of Red-Yellow Latosol (Embrapa, 2006) and Plinthic Gleysol (FAO, 1990) where oscillations and overall lowering of the water table have occurred; 3 ) at low elevations: thick organic ( $\mathrm{H}$, peat layer) horizons overlie Humic Gleysols (FAO, 1990) where surface materials are constantly water-saturated.

At intermediate and low elevations there are iron duricrust horizons (Dc) that contain recognizable plant remains of a peat layer (H horizon). The upper iron duricrust from the plinthic gleysol is a few meters wide and located at an elevation of $974 \mathrm{~m}$ ( $\mathrm{A}$ in Figs. 1 and 2a). The lower iron duricrust from the humic gleysol is approximately $2 \mathrm{~m}$ wide and located at an elevation of $972 \mathrm{~m}$ (B in Figs. 1 and 2b).

In order to assess the formation of both upper and lower iron duricrusts we conducted a detailed petrographic study of a soil previously analysed (Table 1 ). For the lower iron duricrust, 7 samples of $0.3 \mathrm{~kg}$ were continuously sampled along a soil exposure (Table 2). Six samples of $0.3 \mathrm{~kg}$ were randomly hand picked from the upper iron duricrust (Table 3). Additionally, a peat sample without duricrust located at $1200 \mathrm{~m}$ from the lower iron duricrust and at a lower elevation (962 m) was collected (C in Figs. 1 and 2c). The samples were air-dried and macroscopically described. Mineralogical and petrographical analyses were done by using an XRD diffractometer (Philips PW1729) and optical and electron microscopes.

Samples were grind to homogenized powder before subsampling for the following isotopic and chemical analyses. In order to determine the age and the timing of the ferruginous process, conventional ${ }^{14} \mathrm{C}$ dating of organic matter (Centre de Datation par le
Radiocarbone, Lyon, France) of the lower iron duricrust and of the peat developed in the hydromorphic zone (without duricrust) were performed. To avoid any contamination by younger plant material, portions with visible roots were mechanically eliminated from the samples. Chemical analysis of major elements and of $C$ was done on sub-samples by using ICP/AES, after fusion with Li Methaborate at $1000^{\circ} \mathrm{C}$ (RSD of about $10 \%$ ), and a $\mathrm{C}-\mathrm{H}-\mathrm{N}$ analyser (RSD of about $5 \%$ ). Bulk density was done using the classical isovolumetric method.

\section{Results}

\subsection{Upper iron duricrust}

Macroscopic examination showed that the iron duricrust contains two different textural facies (Fig. 2a): 1) a dark-red, hard framework and 2) a white to orange friable facies filling the pores in the hard framework. The relationship between facies and chemical composition is illustrated in Table 3 . The hard framework is mainly composed of iron with $\mathrm{Fe}_{2} \mathrm{O}_{3}$ contents reaching nearly $800 \mathrm{~g} / \mathrm{kg} \mathrm{Al}$ and $\mathrm{Si}$ contents are also significant $\left(\mathrm{Al}_{2} \mathrm{O}_{3}\right.$ near $30 \mathrm{~g} / \mathrm{kg}$ and $\mathrm{SiO}_{2}$ near $10 \mathrm{~g} / \mathrm{kg})$. The friable facies contains less $\mathrm{Fe}_{2} \mathrm{O}_{3}(480-577 \mathrm{~g} / \mathrm{kg})$ but higher amounts of $\mathrm{SiO}_{2}(51-138 \mathrm{~g} / \mathrm{kg}) \mathrm{Al}_{2} \mathrm{O}_{3}(168-202 \mathrm{~g} / \mathrm{kg})$ and $\mathrm{TiO}_{2}(47-129 \mathrm{~g} / \mathrm{kg})$. X-ray analysis showed that the composition of the iron crust is dominated by goethite with minor amounts of hematite, gibbsite, kaolinite and quartz. The hard framework is mostly composed of goethite and hematite while the friable facies is composed of kaolinite, gibbsite and goethite. Quartz is present in both textural facies but is more common in the friable facies. In thin sections, the hard framework shows a dark-brown ferruginous and massive facies (un-structured) consisting of hematite and goethite and pore filling consisting of goethite.

Microscopic examination of the iron duricrust showed that it consists of well-preserved cell root structures (lumen and walls) but the original carbon has nearly totally disappeared $(2.7-6.4 \mathrm{~g} / \mathrm{kg}$ C, Table 3 ). About $40 \%$ of the volume of the iron duricrust is occupied by recognizable cell structures. The cell lumens are totally or partly filled by pore lining goethite and hematite. Pore fillings are sometimes attached to quartz grains suggesting that the iron duricrust formation is not the result of above-ground living-tissue replacement but took place within the soil. The examination showed that pore lining iron oxides consist of approximately 1-8 superposed bands each approximately $100 \mu \mathrm{m}$ thick (Fig. 3). The cell structures are less common in the iron duricrust dominated by the friable facies.

\subsection{Lower iron duricrust}

The elemental composition showed a linear decrease of $C$ contents from the bottom peat horizon to the top surface (Table 2). Carbon decrease is accompanied by a linear increase of iron content from samples Pr2-3 to Pr2-6. In agreement with the chemical data, the XRD study showed an increase in goethite and the presence of hematite at $20-40 \mathrm{~cm}$ (samples Pr2-5 and Pr2-6, Table 2 and Fig. 4). The Si- and Al-bearing minerals are kaolinite, quartz and gibbsite (Fig. 4). The distribution of $\mathrm{Al}$ and $\mathrm{Si}$ is similar to $\mathrm{C}$ except in the top sample. In the top $20 \mathrm{~cm}(\operatorname{Pr} 2-7)$, the iron content is lower than in the bottom-most iron duricrust samples something consistent with a lower abundance of goethite and the disappearance of hematite. The concentration of the other analysed elements is low and showed no significant variation with depth (Table 4)

\subsection{Dating}

The peat below the lower iron duricrust (Pr2-4) has been dated at 27,095 $\pm 865 \mathrm{yr} \mathrm{BP}$ (not calibrated) while the organic matter 




duricrust $(974 \mathrm{~m}), \mathrm{B}=$ the lower iron duricrust $(972 \mathrm{~m})$ and $\mathrm{C}=$ the peat soil without duricrust $(962 \mathrm{~m})$. A, B and C are also referring to Fig. $2 \mathrm{a}-\mathrm{c}$. 


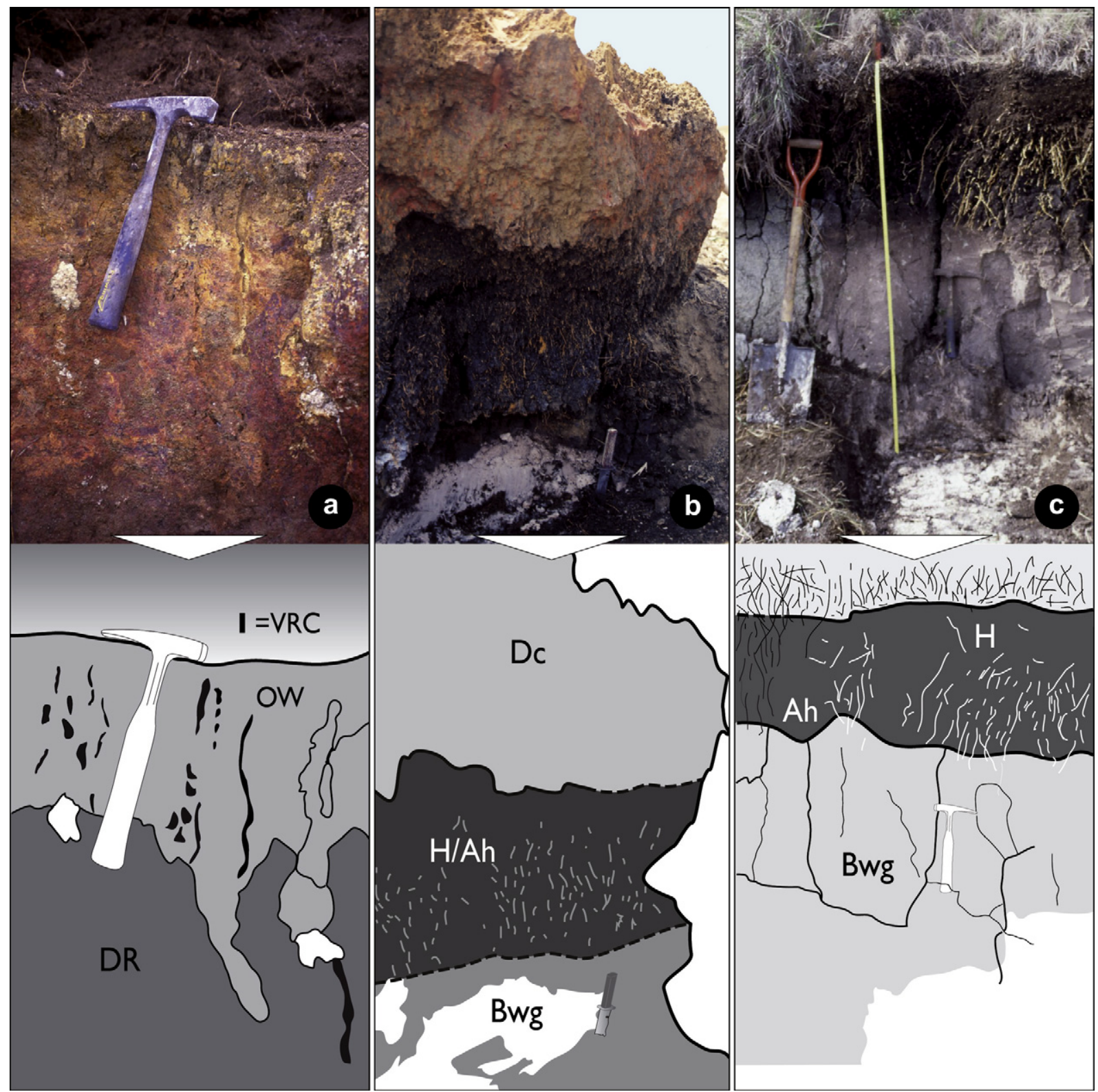

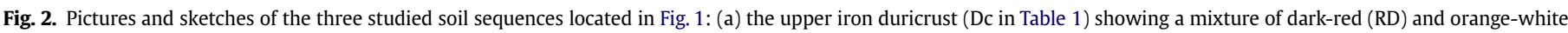

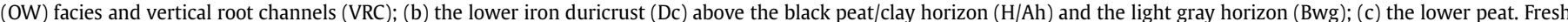

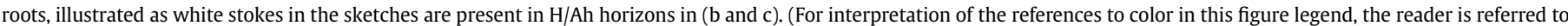
the web version of this article.)

Table 1

General characteristics of the soil at intermediate and lower elevations (Varajão et al., 2000, 2007).

\begin{tabular}{|c|c|c|c|}
\hline Soil name & Horizon & Depth (m) & Description \\
\hline \multicolumn{4}{|c|}{ Intermediate elevation } \\
\hline \multirow[t]{4}{*}{ Plinthic Gleysol } & Dc & $0-0.5$ & $\begin{array}{l}\text { Reddish brown ( } 5 \text { yr } 5 / 3 \text { ) ferruginous duricrust with abundant vertical root channels. } \\
\text { Gradual boundary to }\end{array}$ \\
\hline & Ah & $0.5-0.8$ & $\begin{array}{l}\text { Dark gray ( } 5 \text { yr } 4 / 1) \text { to gray ( } 5 \text { yr } 6 / 1) \text { clay, massive structure with very fine vertical } \\
\text { root channels in the top }(0-0.30 \mathrm{~cm} \text { ). Gradual boundary to }\end{array}$ \\
\hline & Bwg1 & $0.8-2.0$ & $\begin{array}{l}\text { Pink ( } 5 \mathrm{yr} 7 / 3 \text { ) clay, soft, massive structure, presence of ferruginous light red nodules } \\
\text { and irregular mottling in a diffuse contact with the matrix. Gradual boundary to }\end{array}$ \\
\hline & Bwg2 & $2.0-2.1$ & $\begin{array}{l}\text { Pinkish gray ( } 5 \text { yr } 7 / 2 \text { ) clay, soft, massive structure. Presence of light reddish irregular } \\
\text { mottling. }\end{array}$ \\
\hline \multicolumn{4}{|r|}{ 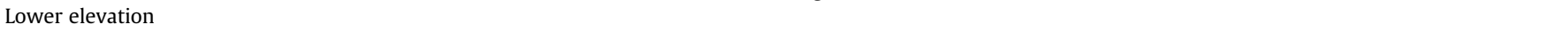 } \\
\hline \multirow[t]{4}{*}{ Humic Gleysol } & Dc & $0-0.8$ & $\begin{array}{l}\text { Reddish brown ( } 5 \text { yr } 5 / 3 \text { ) ferruginous duricrust with abundant vertical root channels. } \\
\text { Gradual boundary to }\end{array}$ \\
\hline & $\mathrm{H}$ & $0.8-1.8$ & Black ( 5 yr $2.5 / 1$ ) to very dark gray ( 5 yr $3 / 1$ ) layer of peat. Gradual boundary to \\
\hline & Ah & $1.8-2.8$ & $\begin{array}{l}\text { Dark gray ( } 5 \text { yr } 4 / 1 \text { ) to gray ( } 5 \text { yr } 6 / 1 \text { ) clay, soft, massive structure. Presence of very fine } \\
\text { vertical root channels in the top. Gradual boundary to }\end{array}$ \\
\hline & Bwg & $2.8->3.0$ & Light gray (5 yr 7/1) clay, soft, massive structure. \\
\hline
\end{tabular}


Table 2

Sampling depth and analytical data of the samples taken from the lower iron duricrust.

\begin{tabular}{|c|c|c|c|c|c|c|c|c|c|c|c|c|c|c|c|c|c|}
\hline Sample & $\begin{array}{l}\text { Depth } \\
(\mathrm{cm})\end{array}$ & Horizon $^{a}$ & $\begin{array}{l}\text { Main minerals } \\
(\mathrm{DRX})^{\mathrm{b}}\end{array}$ & $\begin{array}{l}\text { Density } \\
\left(\mathrm{g} / \mathrm{cm}^{3}\right)\end{array}$ & $\begin{array}{l}\mathrm{SiO}_{2} \\
(\mathrm{~g} / \mathrm{kg})\end{array}$ & $\begin{array}{l}\mathrm{Al}_{2} \mathrm{O}_{3} \\
(\mathrm{~g} / \mathrm{kg})\end{array}$ & $\begin{array}{l}\mathrm{Fe}_{2} \mathrm{O}_{3} \\
(\mathrm{~g} / \mathrm{kg})\end{array}$ & $\begin{array}{l}\mathrm{TiO}_{2} \\
(\mathrm{~g} / \mathrm{kg})\end{array}$ & $\begin{array}{l}\mathrm{MgO} \\
(\mathrm{g} / \mathrm{kg})\end{array}$ & $\begin{array}{l}\mathrm{CaO} \\
(\mathrm{g} / \mathrm{kg})\end{array}$ & $\begin{array}{l}\mathrm{P}_{2} \mathrm{O}_{5} \\
(\mathrm{~g} / \mathrm{kg})\end{array}$ & $\begin{array}{l}\mathrm{K}_{2} \mathrm{O} \\
(\mathrm{g} / \mathrm{kg})\end{array}$ & $\begin{array}{l}\mathrm{Na}_{2} \mathrm{O} \\
(\mathrm{g} / \mathrm{kg})\end{array}$ & $\begin{array}{l}\mathrm{MnO} \\
(\mathrm{g} / \mathrm{kg})\end{array}$ & $\begin{array}{l}\mathrm{H}_{2} \mathrm{O}^{+} \\
(\mathrm{g} / \mathrm{kg})\end{array}$ & $\begin{array}{l}\mathrm{H}_{2} \mathrm{O}^{-} \\
(\mathrm{g} / \mathrm{kg})\end{array}$ & $\begin{array}{l}\mathrm{C} \\
(\mathrm{g} / \mathrm{kg})\end{array}$ \\
\hline Pr2-7 & $0-20$ & Dc & $\begin{array}{l}\text { Gbs; Kln; Qtz; } \\
\text { Gt; Ant }\end{array}$ & 1.18 & 69.2 & 220.3 & 328.3 & 11.2 & 9.3 & 3.0 & 2.0 & 0.3 & 0.4 & 0.2 & 323.1 & 31.4 & 3.9 \\
\hline Pr2-6 & $20-30$ & Dc & $\begin{array}{l}\text { Gbs; Kln; Qtz; } \\
\text { Gt; Hem }\end{array}$ & 1.22 & 47.5 & 100.5 & 600.9 & 7.2 & 9.0 & 7.0 & 8.0 & 0.3 & 0.4 & 0.2 & 169.6 & 23.8 & 31.9 \\
\hline Pr2-5 & $30-40$ & Dc & $\begin{array}{l}\text { Gbs; Kln; Qtz; } \\
\text { Gt; Hem; Ant }\end{array}$ & 1.22 & 71.7 & 174.9 & 417.4 & 12.4 & 9.4 & 3.1 & 2.8 & 0.3 & 0.4 & 0.3 & 272.9 & 29.1 & 77.6 \\
\hline Pr2-4 & $40-52$ & $\mathrm{H} / \mathrm{Ah}$ & $\begin{array}{l}\text { Gbs; Kln; Qtz; } \\
\text { Ant; Gt; Ant }\end{array}$ & 0.9 & 94.0 & 214.4 & 251.4 & 145.0 & 9.9 & 2.6 & 0.3 & 0.3 & 8.0 & 0.2 & 362.1 & 37.9 & 122.4 \\
\hline Pr2-3 & $52-62$ & $\mathrm{H} / \mathrm{Ah}$ & $\begin{array}{l}\text { Gbs; Kln; Qtz; } \\
\text { Gt; Ant }\end{array}$ & $0.92^{\mathrm{c}}$ & 105.3 & 287.2 & 77.2 & 19.6 & 9.9 & 4.0 & 1.4 & 0.3 & 0.4 & 0.2 & 425.0 & 66.4 & 172.6 \\
\hline Pr2-2 & $62-74$ & $\mathrm{H} / \mathrm{Ah}$ & $\begin{array}{l}\text { Gbs; Kln; Qtz; } \\
\text { Ant }\end{array}$ & 0.93 & 111.7 & 354.8 & 30.0 & 22.9 & 9.9 & 4.0 & 1.4 & 0.3 & 0.4 & 0.2 & 428.9 & 39.3 & 158.0 \\
\hline
\end{tabular}

${ }^{a}$ See description in Varajão et al. (2007).

b Gbs = gibbsite; Kln = kaolinite; Qtz = quartz; Ant = anatase; Gt = goethite; Hem = hematite.

c Not measured; estimated taken the average value between the surrounding samples.

trapped in the iron duricrust (Pr2-5) is slightly younger with and dated at 24,615 $\pm 790 \mathrm{yr}$ BP (not calibrated). The age of the peat without duricrust (Fig. 2c) is younger than the previous samples with a calibrated BC age of 4941-4538 yr BP.

\section{Discussion}

\subsection{Evidences for peat-derived duricrusts}

Comparison of the chemistry and mineralogy of the upper and lower iron duricrusts does not show significant differences except for the $\mathrm{C}$ content; this is well illustrated by the composition of sample 6 (Table 3 ), a mixture of facies 1 and 2 of the upper iron duricrust, and of sample Pr2-6 of the lower iron duricrust. We have not separated the facies in the lower iron duricrust but petrographic observations show that it contains facies similar to the ones observed in the upper iron duricrust.

Field and petrographical data show that the iron duricrusts are the result of a combination of iron accumulation in the cell lumen and iron replacement of the organic matter of the peatlands. According to Tardy (1993), 1) goethite is the result of precipitation of iron in the pores of soils underneath the groundwater level and/or in large pores of soils above the groundwater level during the rainy season; 2) hematite precipitates preferentially above the groundwater level in the micropores of the soils. Hematite may also precipitate by transformation and dehydration of goethite accumulated in a hydrated environment (Ambrosi and Nahon, 1986; Tardy, 1993). This process can explain the occurrence of hematite at the top of the lower iron duricrust.

The peat exhibits a large range of porosity/micropores in the fine structure of plants may have been preferential sites for hematite precipitation (Tardy, 1993), while large tubular pores formed by mineralisation of root organic material may have enabled a more intense circulation of solutions favorable to goethite precipitation.
The simultaneous presence of both a waterlogged environment and Al-availability even in very fine pores, favors, in the first stage, goethite and not hematite crystallization (Varajão et al., 2007). According to Varajão et al. (2007), the ferruginization in the $\mathrm{H}$ horizon begins with the formation of strongly Al-substituted goethite with average particles of $20 \mathrm{~nm}$ in size. Small particles of goethite and hematite coexist in the Dc horizon, and they show small values of Al-for-Fe substitution, but much less than in the $\mathrm{H}$ horizon.

Where did Fe come from? The presence of large amount of organic matter (i.e. peat) and water saturation create a favorable geochemical environment for the destruction of $\mathrm{Fe}^{3+}$ minerals, iron reduction to $\mathrm{Fe}^{2+}$ and its release to soil solution. Iron will stay in the reduced form as long as the redox potential is low; if the geochemical environment turns to oxidizing conditions, the iron can precipitate as secondary $\mathrm{Fe}^{3+}$ minerals. This might be particularly the case when groundwater which migrates by hydrostatic forces comes close to the surface along the sideslopes. Part of the iron may also have entered the peatland in run-off waters arriving to the surface. The origin of iron is most probably the lateritic soils located upslope (Varajão et al., 2000) that has been reduced and transported under the peat cover.

The chemical and mineralogical composition of the iron duricrust is similar to previously described iron duricrusts such as those formed under humid tropical climates above ultrabasic rocks by Tardy (1993) found in Guinea and New Caledonia. The iron content of the duricrusts is comparable to those given for the hardened iron horizons also called bog iron ores that are well known in Europe and America (Kaczorek and Sommer, 2003). The micromorphological examination of the bog iron ores shows the presence of minor organic matter remains impregnated by iron (Kaczorek et al., 2004) but the general expression of iron minerals form a groundmass of aggregate microstructure. According to Kaczorek et al. (2004) the formation of the iron hardened horizons

Table 3


examinations.

\begin{tabular}{|c|c|c|c|c|c|c|c|c|c|c|c|c|c|}
\hline Facies $^{\mathrm{a}}$, & $\begin{array}{l}\mathrm{SiO}_{2} \\
(\mathrm{~g} / \mathrm{kg})\end{array}$ & $\begin{array}{l}\mathrm{Al}_{2} \mathrm{O}_{3} \\
(\mathrm{~g} / \mathrm{kg})\end{array}$ & $\begin{array}{l}\mathrm{Fe}_{2} \mathrm{O}_{3} \\
(\mathrm{~g} / \mathrm{kg})\end{array}$ & $\begin{array}{l}\mathrm{TiO}_{2} \\
(\mathrm{~g} / \mathrm{kg})\end{array}$ & $\begin{array}{l}\mathrm{MgO} \\
(\mathrm{g} / \mathrm{kg})\end{array}$ & $\begin{array}{l}\mathrm{CaO} \\
(\mathrm{g} / \mathrm{kg})\end{array}$ & $\begin{array}{l}\mathrm{P}_{2} \mathrm{O}_{5} \\
(\mathrm{~g} / \mathrm{kg})\end{array}$ & $\begin{array}{l}\mathrm{K}_{2} \mathrm{O} \\
(\mathrm{g} / \mathrm{kg})\end{array}$ & $\begin{array}{l}\mathrm{Na}_{2} \mathrm{O} \\
(\mathrm{g} / \mathrm{kg})\end{array}$ & $\begin{array}{l}\mathrm{MnO} \\
(\mathrm{g} / \mathrm{kg})\end{array}$ & $\begin{array}{l}\mathrm{H}_{2} \mathrm{O}^{+} \\
(\mathrm{g} / \mathrm{kg})\end{array}$ & $\begin{array}{l}\mathrm{H}_{2} \mathrm{O}^{-} \\
(\mathrm{g} / \mathrm{kg})\end{array}$ & $\begin{array}{l}\text { C } \\
(\mathrm{g} / \mathrm{kg})\end{array}$ \\
\hline 1 & 12.8 & 32.1 & 775.6 & 2.0 & 1.6 & 0.1 & 0.1 & 0.3 & 1.4 & $<0.1$ & 110.3 & 14.9 & 2.7 \\
\hline $1 \pm 2$ & 11.2 & 31.7 & 793.5 & 2.0 & 0.1 & 0.1 & 0.1 & 0.3 & 1.4 & $<0.1$ & 106.5 & 48.4 & 2.7 \\
\hline $1 \pm 2$ & 28.5 & 63.9 & 693.8 & 5.0 & 1.2 & 0.2 & 0.1 & 0.4 & 1.4 & $<0.1$ & 111.5 & 96.3 & 6.4 \\
\hline $1 \pm 2$ & 26.6 & 81.4 & 638.5 & 5.7 & 1.9 & 0.1 & 0.1 & 0.3 & 1.9 & $<0.1$ & 112.5 & 132.8 & 6.2 \\
\hline $2 \pm 1$ & 137.9 & 201.6 & 480.4 & 4.7 & 0.2 & 0.2 & 0.1 & 0.3 & 1.9 & $<0.1$ & 148.4 & 13.6 & 4.0 \\
\hline $2 \pm 1$ & 51.4 & 168.3 & 576.9 & 12.9 & 0.1 & 0.2 & 0.1 & 0.2 & 2.6 & $<0.1$ & 145.2 & 29.0 & 4.9 \\
\hline
\end{tabular}

a Facies 1: hard dark-red framework : goethite, hematite, (quartz, anatase).

b Facies 2: friable white to orange facies : gibbsite, kaolinite, goethite, (quartz, anatase). 

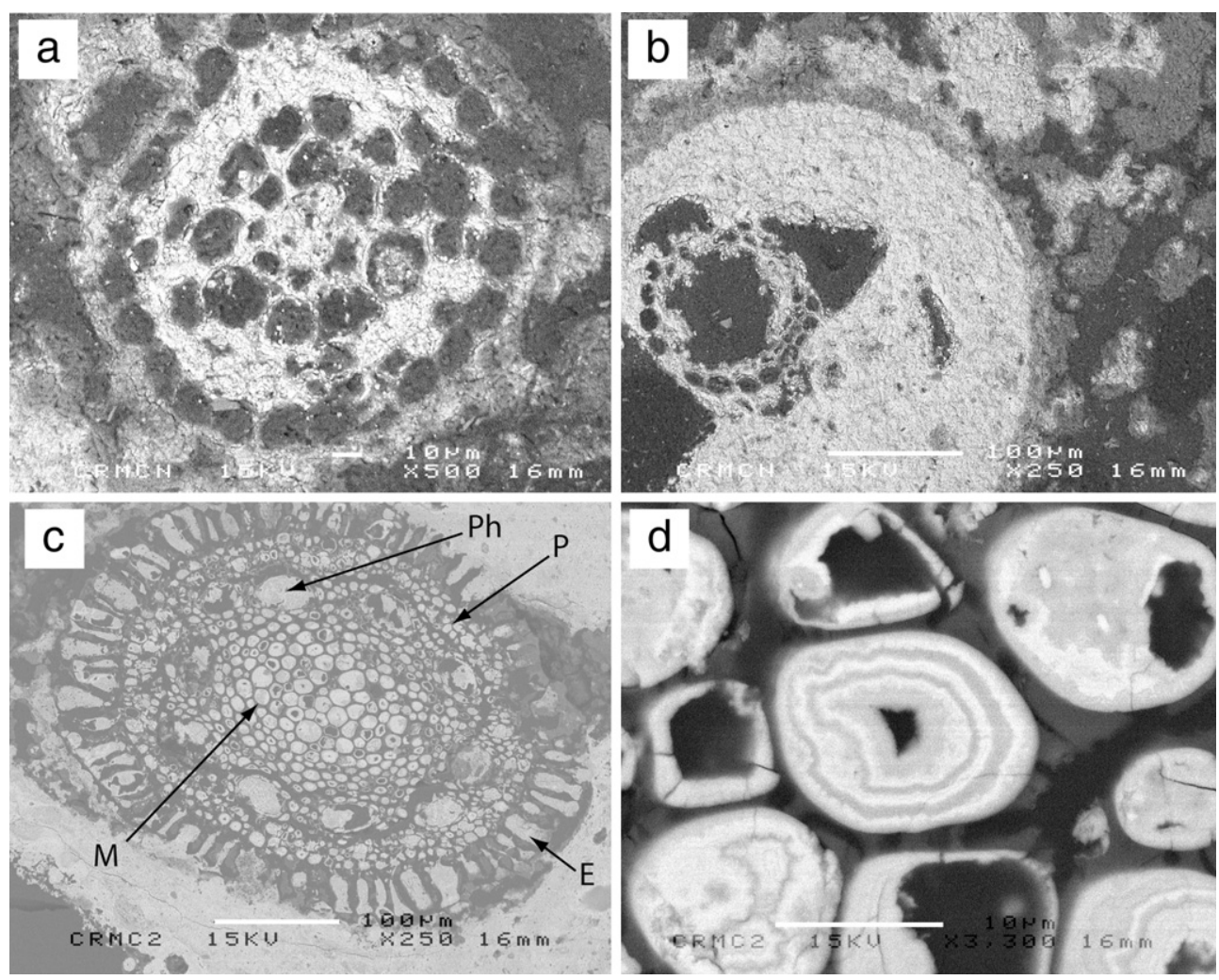



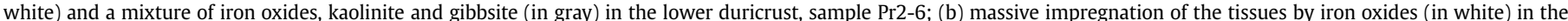

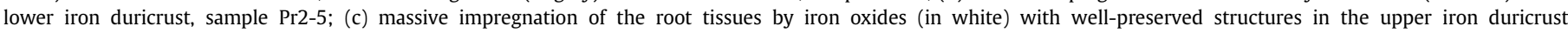

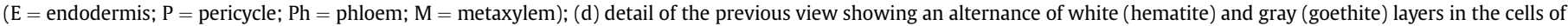
the metaxylem.

results from a lateral transport of water and $\mathrm{Fe}^{2+}$ which, by capillary rise, precipitates in lower terrain which may be occupied by wetlands where the groundwater level comes near the surface. Iron oxides precipitate following a classical redox process, at the interface between a reduced environment that transports iron and an unsaturated oxidizing environment.

Compared to the bog iron ores, the iron duricrusts at Uberaba are much more enriched in root structures. The exceptional conservation of the cell structures show that the rate of ferruginization



Fig. 4. X-ray diffractograms of the samples from the lower duricrust (the abbreviations are given in Table 2). was fast compared to the rate of organic matter decomposition. Some bog iron ores with spring iron groundwater can form minable deposits within $25 \mathrm{yr}$ (Moore, 1910). No data are available to estimate the time necessary for the fossilization of plants by iron but if we take the case of fossilization by silica as an analogue, tens to hundreds of years are enough (Akahane et al., 2004). We can assume that the iron duricrusts at Uberaba were formed during a short period of time, geologically speaking, by a redox mechanism similar to the one assumed for the formation of bog iron.

\subsection{Succession of duricrusts processes}

The peat not capped by a duricrust is younger than the one capped by the iron duricrust (Table 4). The upper iron duricrust was not dated but if we consider the lack of peat below it and its lower content of $\mathrm{C}$, we can infer that it is older than the lower iron duricrust. The succession of the two iron duricrusts at different elevations is therefore most probably the result of

Table 4

Dating results.

\begin{tabular}{|c|c|c|c|}
\hline Sample & Lab code & $\begin{array}{l}\text { Conventional } \\
\text { radiocarbon } \\
\text { age BP }\end{array}$ & 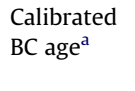 \\
\hline $\begin{array}{l}\text { Peat without } \\
\text { duricrust (Fig. 2c) }\end{array}$ & LY-11315 & $5880 \pm 90$ & $4941-4538$ \\
\hline Pr2-5 (Table 2) & LY-11314 & $24,615 \pm 790$ & - \\
\hline Pr2-4 (Table 2) & LY-11313 & $27,095 \pm 865$ & - \\
\hline
\end{tabular}

${ }^{a}$ Using the calibration curve of Stuiver et al. (1998). 
a lowering of the groundwater level. In wetland species, diffusion of oxygen within the roots can lead to the precipitation of iron oxides (Marschner, 1995) but it is unlikely that such a mechanism can lead to a pervasive iron oxide cementation following the peat destruction, otherwise peat ferruginization would be frequently observed throughout the world, which is not the case. Besides, the reducing environment in the peat maintains $\mathrm{Fe}^{2+}$ in solution. The most likely explanation of the peat-derived duricrust is therefore a lowering of the groundwater level leading to upward migration of $\mathrm{Fe}^{2+}$ preferentially through the highly porous root canals, and its eventual precipitation into iron oxides. The following scenario takes into account the three types of soils observed in the field:

1. Development of peat horizon below groundwater level with abundant Cyperaceae roots near the surface;

2. Drop of groundwater level and formation of the iron duricrust;

3. Conservation of the iron duricrust above the water table and (nearly) complete removal of the carbon from the former peat;

4. Dismantlement of the iron duricrusts. The presence of fresh roots in the soils (Fig. $2 \mathrm{~b}$ and c) as well as the depletion of iron oxi-hydroxides at the top of the lower one suggests that the iron duricrust have been subjected to recent degradation probably due to the return of episodic hydromorphic conditions.

Several mechanisms may have triggered the hydrologic changes that caused the oxidation of peatland and its replacement by iron oxides: draining of the area by the population for agricultural purposes; a tectonic influence leading to an uplift of the area followed by a lowering of the groundwater level and a drier climatic regime leading to a lowering of the groundwater level. The first mechanism is unlikely because there is no evidence that the peatland have been drained in the past and because agriculture evidences were not found in the study area for the historical and pre-historical times.

Tectonic uplift in the South American platform has been occurring since the Lower Tertiary (Saadi, 1993; Riccomini and Assumpção, 1999). The uplift of the borders of the tectonic plates could be due to isostatic compensation derived from the orogeny of the active borders (Summerfield, 1991). Saadi (1993) denominated the last two Andean events as "neotectonic" and proposed a more recent tectonic pulse between the Lower and the Medium Pleistocene. These neotectonic evidences have also been observed in the centre of the Minas Gerais state, by the integrated analysis of quantitative data of erosion rates $\left({ }^{10} \mathrm{Be}\right)$ and by the immature character of the soils developed from the main proterozoic rocks of the region that showed a mean rate of erosion of $7 \mathrm{~m}$ during the last 1000 kyr (Varajão et al., 2009). However, evidences are lacking for a neotectonic event during late Quaternary.

During late Quaternary, climatic events dryer than present have been suggested by several studies using palynological records and charcoal analysis in central Brazil: 50-40 kyr (Ledru et al., 1996); 40-30 kyr PB (Ledru et al., 2009); 35-17 kyr BP (dry and cold, Behling and Lichte, 1997); 23-12 kyr BP (Ledru et al., 2009); ca 19ca 7 kyr BP (Salgado-Labouriau et al., 1998); 17-14 kyr BP (Ledru, 1993); 11-10 kyr BP (dry and cold, Ledru, 1993) and 6.4-4 kyr BP (Pessenda et al., 2004).

Therefore the observed iron duricrusts at different levels in our study could be the consequence of one or several dryer climatic events during the late Quaternary: the upper crust is compatible with a dry phase occurred at 50-40 kyr BP found by Ledru et al. (1996) while the lower crust could have been formed during one of the several dry periods identified since the formation of the lower crust, ca 24-27 kyr BP.

\subsection{Rate of peat oxidation}

The gain (fluxes + ) or loss (fluxes -) of the elements in the lower iron duricrust can be calculated using a classical isovolume mass balance approach because the preservation of the root structures in the iron duricrust is a good evidence that the original peat architecture has not been changed. For a given element $i$ in a sample $j$, the weight variation or flux $\left(f_{i, j}\right)$ is given by:

$f_{i, j}\left(\mathrm{~kg} / \mathrm{m}^{3}\right)=\left(\left(C_{i, j} * d_{j}\right)-\left(C_{i, p} * d_{p}\right)\right) * 10$

where: $C_{i, j}=$ concentration of $i$ in sample $j$ in weight \%; $d_{j}=$ apparent density of sample $j$; $C_{i, p}=$ concentration of $i$ in the original peat and $d_{p}=$ apparent density of the original peat. We assume that the composition of the original peat; i.e. before oxidation, is represented by sample $\operatorname{Pr} 2-2$.

Our calculation shows that $383 \mathrm{~kg} / \mathrm{m}^{3}$ of $\mathrm{C}\left(1462 \mathrm{~kg} / \mathrm{m}^{3} \mathrm{CO}_{2}\right)$ were exported from the soil at the lower elevation together with 25 and $161 \mathrm{~kg} / \mathrm{m}^{3}$ of $\mathrm{Si}$ and $\mathrm{Al}$ while $625 \mathrm{~kg} / \mathrm{m}^{3}$ of $\mathrm{Fe}$ have been accumulated (Table 5).

The rate of peat oxidation can be estimated using the age of the peat constrained by the ages of the dry periods given in the literature commented above. A maximum duration of $28 \mathrm{kyr}$, approximately the maximum age of the basal peat layer, can be estimated if we assume that the iron duricrusts are the result of the accumulated effect of all the dry events occurring since the formation of the peat.This estimation is probably too high as shown by the evidences of recent peat destruction at the top of the lower iron duricrust. Alternately, the duration of the oxidation event could have been a low as 1000 yr taking the data of Ledru (1993). Therefore, the duration of the oxidation event may be reasonably assumed to have ranged between 1 and $28 \mathrm{kyr}$. The calculation of the atmospheric input of $C$ following theses assumptions gives a range of $14-383 \mathrm{~g} / \mathrm{m}^{3} / \mathrm{yr}$. Given the thickness of the profile $(0.62 \mathrm{~m}), 0.08-2.26 \mathrm{~kg} \mathrm{CO}_{2} \mathrm{~m}^{-2} \mathrm{yr}^{-1}$ has been released out of the peat assuming that all the organic carbon is mineralized into $\mathrm{CO}_{2}$.

Our estimation can be discussed with the various causes of peat degradation reported in the literature. The first cause of peatland loss is fire. Page et al. (2002) have shown that during the $1997 \mathrm{El}$ Nino event in Indonesia, 234-285 $\mathrm{kg} \mathrm{CO}_{2} \mathrm{~m}^{-2}$ were releases, representing $13-40 \%$ of the mean annual global carbon emissions from fossil fuels. The second cause is human-induced drainage which follows commercial exploitation particularly under the tropics. The rate of peat oxidation through drainage is still poorly estimated. Joosten (2009) gave a range of default values ranging from $7 \mathrm{t} \mathrm{CO}_{2}$ $\mathrm{ha}^{-1} \mathrm{yr}^{-1}$ for boreal forest to $40 \mathrm{t} \mathrm{CO}_{2} \mathrm{ha}^{-1} \mathrm{yr}^{-1}$ for tropical forest $\left(0.7-4 \mathrm{~kg} \mathrm{CO}_{2} \mathrm{~m}^{-2} \mathrm{yr}^{-1}\right)$. Kool et al. (2006) calculated an emission of $4.2-85.9 \mathrm{~kg} \mathrm{~m}^{-2} \mathrm{CO}_{2}, 6$ years after compaction of peat domes in Indonesia $\left(0.7-14 \mathrm{~kg} \mathrm{CO}_{2} \mathrm{~m}^{-2} \mathrm{yr}^{-1}\right)$. A third potential mechanism of destruction of peat and increasing atmospheric $\mathrm{CO}_{2}$ release is thought the predicted global warming and the resulting water table drawdown (Moore, 2002). However, in the Northern peatlands

\section{Table 5}

Mass balance calculations showing the gain of iron and the loss of carbon in the lower iron duricrust.

\begin{tabular}{lllll}
\hline Sample & $\begin{array}{l}\text { Si flux } \\
\left(\mathrm{kg} / \mathrm{m}^{3}\right)\end{array}$ & $\begin{array}{l}\text { Al flux } \\
\left(\mathrm{kg} / \mathrm{m}^{3}\right)\end{array}$ & $\begin{array}{l}\text { Fe flux } \\
\left(\mathrm{kg} / \mathrm{m}^{3}\right)\end{array}$ & $\begin{array}{l}\text { C flux } \\
\left(\mathrm{kg} / \mathrm{m}^{3}\right)\end{array}$ \\
\hline Pr2-7 & -10 & -19 & 126 & -153 \\
Pr2-6 & -21 & -56 & 247 & -119 \\
Pr2-5 & -8 & -31 & 168 & -63 \\
Pr2-4 & -9 & -37 & 69 & -48 \\
Pr2-3 & -4 & -18 & 15 & 0 \\
Pr2-2 & 0 & 0 & 0 & 0 \\
Total & -52 & -161 & 625 & -383 \\
\hline
\end{tabular}


water table drawdown may lead to hydrological and ecological changes that do not necessarily lead to a $\mathrm{CO}_{2}$ atmospheric increase at few year-scale (Strack et al., 2006: Strack and Waddington, 2007).

To sum up, our high range is in a good agreement with the estimations given by Joosten (2009) and Kool et al. (2006) for tropical peatlands. Our low range is however an order of magnitude lower than the data given by Joosten (2009) and Kool et al. (2006) but is still showing a significant contribution of $\mathrm{CO}_{2}$ to the atmospheric release.

\section{Conclusion}

Based on field and laboratory evidences, we showed that fossilization of peat by iron oxides took place in the Uberaba Plateau. The formation of peat-derived duricrusts probably results from a lowering of the groundwater level leading to migration of $\mathrm{Fe}^{2+}$ through the highly porous root canals, and its eventual precipitation into $\mathrm{Fe}^{3+}$ oxides while organic matter was mineralized. The occurrence of iron duricrusts at different elevations is compatible with paleoclimatic reconstructions, which showed several drier climatic events during late Quaternary. Despite large uncertainties for the duration of the dry events, the estimated $\mathrm{CO}_{2}$ emissions during oxidation of the lower peat are $0.08-2.26 \mathrm{~kg} \mathrm{CO}_{2} \mathrm{~m}^{-2} \mathrm{yr}^{-1}$ in a good agreement with emissions from present-day drained peatlands.

\section{Acknowledgement}

We would like to thank IRD, CAPES/COFECUB, CNPq and FAPEMIG for funding this research. Magnesita is thanked for logistic support during fieldwork. The authors are thankful to Jean Jacques Motte and Guilherme F.C.D. Varajão for their contributions in the artwork and Sarah Kirman, Miriam Borba-Roschel and Jean Barth Obame Emvogha for their helpful scientific contributions.

\section{References}

Akahane, H., Furuno, T., Miyajima, H., Yoshikawa, T., Yamamoto, S., 2004. Rapid wood silicification in hot spring water: an explanation of silicification of wood during the earth's history. Sedimentary Geology 169, 219-228.

Ambrosi, J.P., Nahon, D., 1986. Petrological and geochemical differentiation of lateritic iron crust profiles. Chemical Geology 57, 371-393.

Behling, H., Lichte, M., 1997. Evidence of dry and cold climatic conditions at glacial times in tropical southeastern Brazil. Quaternary Research 48, 348-358.

Borba-Roschel, M., Alexandre, A., Varajão, A.F.D.C., Meunier, J.D., Varajão, C.A.C., Colin, F., 2006. Phytoliths as indicators of pedogenesis and paleoenvironmental changes the Brazilian cerrado. Journal of Geochemical Exploration 88, 172-176.

Embrapa, 2006. Sistema Brasileiro de Classificação de Solos. Centro Nacional de Pesquisa de Solos, Rio de janeiro Embrapa.

Evans, M., Lindsay, J., 2010. Impact of gully erosion on carbon sequestration in blanket peatlands. Climate Research 45, 31-41.

FAO, 1990. Guidelines for Soil Profiles Description. FAO, Rome.

Frolking, S., Roulet, N.T., 2007. Holocene radiative forcing impact of northern peatland carbon accumulation and methane emissions. Global Change Biology 13, 1079-1088.

Goodland, R., 1971. A physiognomic analysis of the "cerrado" vegetation of central Brazil. Journal of Ecology 59, 411-419.

Grandin, G., Perseil, E.A., 1977. Le gisement de manganèse de Mokta (Côte d'Ivoire). Transformation minéralogiques des minerais par action météorique. Le Bulletin de la Société géologique de France 7, 309-317.

Joosten, $\mathrm{H}$., 2009. The Global Peatland $\mathrm{CO}_{2}$ Picture. Peatland Status and Drainage Related Emissions in All Countries of the World. Wetlands International.

Kaczorek, D., Sommer, M., 2003. Micromorphology, chemistry, and mineralogy of bog iron ores from Poland. Catena 54, 393-402.
Kaczorek, D., Sommer, M., Andruschkewitsch, I., Oktaba, L., Czerwinski, Z., Stahr, K., 2004. A comparative micromorphological and chemical study of «Raseneisenstein» (bog iron ore) and «Ortstein». Geoderma 121, 83-94.

Kool, D.M., Buurman, P., Hoekman, D.H., 2006. Oxidation and compaction of a collapsed peat dome in Central Kalimantan. Geoderma 137, 217-225.

Lara, R.P., 1997. As argilas do Platô de Uberaba (MG): Micromorfologia, mineralogia e geoquímica. Implicações genéticas. Master Thesis, Federal University of Ouro Preto, Brazil.

Ledru, M.P., Braga, P.I.S., Soubiès, F., Fournier, M., Martin, L., Suguio, K., Turq, B., 1996. The last 50,000 years in the Neotropics (Southern Brazil): evolution of vegetation and climate. Palaeogeography, Palaeoclimatology, Palaeoecology 123, 239-257.

Ledru, M.P., Mourguiart, P., Riccomini, C., 2009. Related changes in biodiversity, insolation and climate in the Atlantic rainforest since the last interglacial. Palaeogeography, Palaeoclimatology, Palaeoecology 271, 140-152.

Ledru, M.P., 1993. Late quaternary environmental and climatic changes in Central Brazil. Quaternary Research 39, 90-98.

Limpens, J., Berendse, F., Blodau, C., Canadell, J.G., Freeman, C., Holden, J., Roulet, N. Rydin, H., Schaepman-Strub, G., 2008. Peatlands and the carbon cycle: from local processes to global implications - a synthesis. Biogeosciences Discuss 5, 1379-1419.

Marschner, H., 1995. Mineral Nutrition of Higher Plants, second ed. Academic Press, London.

Moore, E.J., 1910. The occurrence and origin of some bog iron deposits in the district of Thunder Bay, Ontario. Economic Geology 5, 528-537.

Moore, P.D., 2002. The future of cool temperate bogs. Environmental Conservation 29, 3-30.

Nahon, D., 1991. Introduction to the Petrology of Soils and Chemical Weathering. Wiley, New-York.

Oliveira, P.S., Marquis, R.J., 2002. The Cerrados of Brazil: Ecology and Natural History of a Neotropical Savanna. Columbia University Press, New York.

Page, S.E., Siegert, F., Rieley, J.O., Boehm, H.D.V., Jaya, A., Limin, S., 2002. The amount of carbon released from peat and forest fires in Indonesia during 1997. Nature 420, 6164.

Pailler, D., Flicoteaux, R., Ambrosi, J.P., Médus, J., 2000. Les bois fossiles mio-pliocènes de Nkondo (lac Alberts, Ouganda), composition minéralogique et mode de formation. Comptes Rendus de l'Académie des Sciences Paris, Sciences de la Terre et des Planètes/Earth Planetary Sciences 331, 279-286.

Pessenda, L.C.R., Gouveia, S.E.M., Aravena, R., Boulet, R., Valencia, E.P.E., 2004. Holocene fire and vegetation changes in southeastern Brazil as deduced from fossil charcoal and soil carbon isotopes. Quaternary International 114, 35-43.

Riccomini, C., Assumpcão, M., 1999. Quaternary tectonics in Brazil. Episodes 22 (3), $221-225$

Saadi, A., 1993. Neotectônica da Plataforma Brasileira: esboço e interpretação preliminares. Geonomos 1 (1), 1-15.

Salgado-Labouriau, M.L., Barberi, M., Ferraz-Vicentini, K.R., Parizzi, M.G., 1998. A dry climatic event during the late quaternary of tropical Brazil. Review of Palaeobotany and Palynology 99, 115-129.

Sorensen, K.W., 1993. Indonesian peat swamp forests and their role as a carbon sink. Chemosphere 27, 1065-1082.

Strack, M., Waddington, J.M., 2007. Response of peatland carbon dioxide and methane fluxes to a water table drawdown experiment. Global Biogeochemical Cycles 21, GB1007. http://dx.doi.org/10.1029/2006GB002715.

Strack, M., Waddington, J.M., Rochefort, L., Tuittila, E.S., 2006. Response of vegetation and net ecosystem carbon dioxide exchange at different peatland microforms following water table drawdown. Journal of Geophysical Research 111, G02206. http://dx.doi.org/1011029/2005JG000145.

Stuiver, M., Reimer, P.J., Bard, E., Beck, J.W., Burr, G.S., Hugnen, K.,A., Kromer, B., McCormac, G., van der Plicht, J., Spurk, M., 1998. INTCAL98 radiocarbon age calibration, 20000-0 cal BP. Radiocarbon 40, 1041-1083. 1998 Calibration issue. Radiocarbon 40(3).

Summerfield, M.A., 1991. Global Geomorphology: An Introduction of the Study of Landforms. Longman Scientific \& Technical, New York.

Tardy, Y., 1993. Pétrologie des latérites et des sols tropicaux. Masson, Paris.

Thomas, M.F., 1994. Geomorphology in the Tropics. Wiley, Chisester.

Varajão, A.F.D.C., Lara, R.P., Da Costa, J.I., Boulangé, B., 2000. Mineralogical, morphological and geochemical evolution of the clayey covering of the Uberaba Plateau, Minas Gerais, Brazil. Zentralblat fur Geologie und Palaontologie 7/8, 903-916.

Varajão, A.F.D.C., Gilkes, R.J., Hart, R.D., 2002. Amorphous alumino-silicate materials in a Brazilian hydromorphic lateritic soil. Australian Journal of Soil Research 40, 465-481.

Varajão, A.F.D.C., Da Costa, G.M., Varajão, C.A.C., Meunier, J.D., Colin, F., 2007. Ironbearing phases in a peat-derived duricrust from Brazil. European Journal of Soil Science 58, 1096-1106.

Varajão, C.A.C., Salgado, A.A.R., Varajão, A.F.D.C., Braucher, R., Colin, F., Nalini Jr., H.A., 2009. Estudo da evolução da paisagem do Quadrilátero Ferrífero (Minas Gerais, Brasil) por meio da mensuração das taxas de erosão ( $\left.{ }^{10} \mathrm{be}\right)$ e da pedogênese. Revista Brasileira de Ciências do Solo 33, 1409-1425. 